E-ISSN. 2685-7650

Vol. 1 No. 1 (2019), pp 36-42

DOI: https://doi.org/10.33366/jkn.v1i1.8

\title{
Strategi Komunikasi Pemasaran dalam Meningkatkan Hasil Penjualan di Kampung Keramik Dinoyo Kota Malang
}

\author{
Tarno Maryanto1, Amanah Rakhim Syahida2 \\ 1,2Program Studi Ilmu Komunikasi, Universitas Tribhuwana Tunggadewi \\ Email: tarnomaryanto96@gmail.com
}

\begin{abstract}
A good and effective marketing communication strategy is very important to improve the production and sales targets in Kampung Keramik, Kelurahan Dinoyo, Malang. This research examined how marketing communication strategies increase sales and improve good relations with customers and prospective customers. The purpose of this study was to find out and learn marketing communication strategies to maintain good relationships with customers and prospective customers. This study used a descriptive qualitative, with the data collection technique through in-depth interviews, field observations involving informants and documentation as the main data sources. The results of this study indicated that the marketing communication strategy adopted by Kampung Keramik Dinoyo in increasing sales and maintaining relationships with customers and prospective customers was by conducting market selection strategies, product knowledge strategies, distribution strategies and promotion strategies. In conducting promotional activities to increase the sales in Kampung Keramik Dinoyo by putting advertisments in YouTube channel, Instagram, Facebook, online media and websites. Kampung Keramik Dinoyo also conducted a Direct Marketing and Online Marketing Programs that aimed to expand information networks to attract prospective customers and established good relations with their customers.
\end{abstract}

Keywords: Marketing Communication, Sales, Customers, Dinoyo Ceramics.

\begin{abstract}
Abstrak: Strategi komunikasi pemasaran yang baik dan efektif sangat penting dilakukan untuk meningkatkan hasil produk dan target penjualan di Kampung Keramik Kelurahan Dinoyo Kota Malang. Penelitian ini akan mengkaji secara mendalam bagaimana strategi komunikasi pemasaran dalam meningkatkan penjualan dan meningkatkan hubungan baik dengan customer dan calon custemer. Tujuan penelitian ini adalah untuk mengetahui dan mempelajari strategi komunikasi pemasaran serta menjaga hubungan baik dengan customer dan calon customer. Metode dalam penelitian ini menggunakan deskriptif kualitatif, dengan teknik pengumpulan data melalui wawancara secara mendalam, observasi lapang yang melibatkan informan sebagai sumber informasi terkait pemasaran keramik Dinoyo dan dokumentasi sebagai sumber data utama. Hasil penelitian ini menunjukkan bahwa strategi komunikasi pemasaran yang diterapkan oleh Kampung Wisata Keramik Dinoyo dalam meningkatkan penjualan dan menjaga hubungan dengan customer dan calon customer adalah dengan cara melakukan strategi pemilihan pasar, strategi produk knowlage, strategi distribusi dan strategi promosi produk keramik. Dalam melakukan kegiatan promosi untuk meningkatkan penjualan Kampung Keramik Dinoyo dengan cara Advertising yang dilakukan melalui chanel youtube, instagram, facebook, media online dan website. Kampung Keramik Dinoyo juga melakukan Program Direct Marketing dan Online Marketing yang bertujuan memperluas jaringan informasi agar dapat menarik calon konsumen dan menjalin hubungan baik dengan konsumennya.
\end{abstract}

Kata Kunci : Komunikasi Pemasaran, Penjualan, Customer, Keramik Dinoyo.

\section{Pendahuluan}

Indonesia memiliki perkembangan pesat di beberapa bidang, seperti bidang ilmu pengetahuan, telekomunikasi, teknologi informasi, jaringan transportasi dan sektor-sektor bidang kehidupan lainnya, mengakibatkan arus informasi semakin mudah dan lancar mengalir kepada setiap individu dan kelompok yang membutuhkannya. Secara umum dari segala aspek tersebut, di Indonesia transaksi bisnis sangat cepat dalam perkembangannya. sehingga banyak konsumen yang 


\section{Jurnal Komunikasi Nusantara}

E-ISSN. 2685-7650

Vol. 1 No. 1 (2019), pp 36-42

DOI: https://doi.org/10.33366/jkn.v1i1.8

semakin kritis, dinamis, dan dengan tuntutan yang beragam, sehingga tidak mudah ditebak keinginannya.

Dampak dari perubahan tersebut juga dirasakan oleh para pengrajin dan penjual keramik di Kampung Wisata Dinoyo. Mengingat bahwa produk yang di hasilkan bukan kebutuhan pokok dan juga ketatnya persaingan dagang, beberapa kali pengrajin mengalami kemprosotan penjualan. Upaya dalam mensiasati dampak pada kemunduran dan melemahnya penjualan kerajinan keramik di Kelurahan Dinoyo, Salah satu strategi yang harus dikelola dengan baik adalah strategi komunikasi pemasaran. Hal ini dilakukan agar pengusaha kerajinan keramik di Kelurahan Dinoyo yang termasuk dalam pengusaha kecil, mampu bersaing dengan kompetitor yang ada. Dengan strategi pemasaran yang tepat akan membuat industri kerajinan keramik tetap eksis dan produknya dapat dijadikan sebagai salah satu produk unggulan daerah, khususnya Kota Malang.

Adanya praktik dalam memproduksi dan menjual barang yang sama di Kelurahan Dinoyo dan jarak anatar unit dagang satu dengan yang lainnya berdekatan dapat diasumsikan bahwa hal tersebut dapat memberikan inovatif penjual kerajinan keramik di Kelurahan Dinoyo. Sehingga dapat menunjang dan membantu peran penting paguyuban yang menaungi berjalannya Kampung Wisata Keramik Dinoyo dalam mempersatukan dua hal kedalam kekompakan yaitu kepentingan individu yang berkaitan dengan kerajinan keramik dan kepentingan kelompok yang berkaitan dengan kepentingan organisasi/paguyuban tersebut berjalan dengan baik dan berdiri sampai sekarang. Salah satu usaha yang diterapkan adalah dengan melakukan strategi komunikasi pemasaran yang baik dan efektif untuk melangsungkan penjualan.

Strategi dapat diartikan sebagai suatu garis besar haluan dalam bertindak untuk mencapai sasaran yang telah ditentukan (Asrori, 2016, Chaniago, 2014, Nurcholifah, 2014). Secara umum, strategi komunikasi merupakan bagian dari perencanaan komunikasi guna mencapai maksud yang ingin dicapai (Cangara, 2013). Strategi komunikasi berisi tentang cara menyebarluaskan pesan dari komunikator kepada komunikan yang tepat, melalui saluran dan pada waktu yang tepat (Wijaya, 2015). Rencana komunikasi memiliki tugas utama melakukan identifikasi terhadap kelompok pasar, yang tentu sangat beragam (Afrilia, 2018). Dikutip dari Patrick, identifikasi perlu dilakukan karena lingkungan masyarakat memiliki kebutuhan dan tren yang berbeda-beda (Suwatno, 2017). Komunikasi pemasaran merupakan peristiwa komunikasi yang menggunakan media tertentu, dengan tujuan untuk merubah pengetahuan, sikap, dan tindakan khalayak sesuai yang dikehendaki oleh komunikator (Kusniadji, 2016, Kurnianti, 2017). Dikutip dari Basu Swastha, komunikasi pemasaran merupakan komunikasi yang berlangsung antara penjual dan pembeli, yang juga ikut serta dalam pengambilan keputusan dalam bidang pemasaran (Aprilya, 2017).

\section{Metode Penelitian}

Penelitian ini dimulai dengan melakukan wawancara, dokumentasi dan pengumpulan data dengan cara observasi ke lapangan yaitu di J1. MT. Haryono IX, Dinoyo, Kota Malang. Metode penelitian yang digunakan adalah penelitian kualitatif deskriptif, yaitu untuk mendeskripsikan dan menggambarkan fenomena-fenomena yang ada, baik bersifat alamiah maupun rekayasa manusia, yang lebih memperhatikan mengenai karakteristik, kualitas, keterkaitan antar kegiatan untuk mendapatkan gambaran secara menyeluruh dan mendalam tentang Strategi Komunikasi 


\section{Jurnal Komunikasi Nusantara}

E-ISSN. 2685-7650

Vol. 1 No. 1 (2019), pp 36-42

DOI: https://doi.org/10.33366/jkn.v1i1.8

Pemasaran yang dilakukan oleh pihak Kampung Wisata Keramik Dinoyo dalam memasarkan produk kepada konsumen. Peneliti mewawancarai key informant untuk memperoleh informasi tentang bagaimana strategi komunikasi pemasaran Kampung Wisata Keramik Dinoyo.

Pengumpulan data dalam penelitian ini dengan cara melakukan observasi, wawancara dengan key informant serta studi dokumentasi. Data penelitian hasil wawancara dicatat dan direkam selalui teknik pengamatan langsung dan wawancara mendalam. Dokumentasi juga digunakan sebagai teknik pengumpulan data penunjang. Pengamatan dilakukan peneliti terhadap bentuk komunikasi pemasaran yang digunakan baik advertising, sales promotion, personal selling, publisitas dan event. Wawancara banyak dilakukan dalam posisi informan berada di lokasi untuk memperoleh data-data tentang strategi komunikasi pemasaran yang dilaksanakan Kampung Wisata Keramik Dinoyo. Hasil pengamatan dan wawancara yang diperoleh dari key informant kemudian dikumpulkan dan setelah itu dilakukan reduksi data.

Dalam proses memeriksa realibilitas dan validitas data, peneliti menggunakan triangulasi metode. Jika informasi yang diperoleh berasal dari hasil wawancara misalnya, perlu diuji dengan hasil observasi dan seterusnya.

\section{Hasil dan Pembahasan}

\section{Strategi Komunikasi Pemasaran Kampung Wisata Keramik Dinoyo dalam Meningkatkan Penjualan}

\section{a. Strategi Pemilihan Pasar}

Pemilihan pasar untuk penjualan produk yang dilakukan oleh pemilik usaha Kampung Keramik Dinoyo betujuan untuk melihat adanya peluang yang potensial terhadap usaha dan produk yang dimilikinya. Adanya persaingan, persamaan dan juga perbedaan produk menyebabkan pemilik usaha yang terlibaat menyiapkan manajemen yang baik dan juga strategi dalam pemasarannya dengan cara mengelompokkan pasar-pasar yang ada dalam rangka memahami struktur pasar yang akan menjadi targetnya.

\section{b. Strategi Produk Keramik}

Salah satu pokok penting yang dapat mempengaruhi tanggapan konsumen yang ruang geraknya masih dalam jangkauan adalah produk. Strategi atau kebijakan penting yang diambil Kampung Wisata Keramik Dinoyo dalam hubunganya dengan produk keramik Dinoyo adalah dipusatkan pada kualitas barang serta proses pengerjaanya. Jumlah produk barang yang sudah beredar dari masing-masing pengrajin mengakibatkan keadaan pasar menjadi arena persaingan mutu produk barang keramik tersebut. Dalam menanggapi hal ini paguyuban Kampung Wisata Keramik Dinoyo menjaga kualitas produk barang yang diproduksinya. Hal ini benar-benar dilakukan untuk nama baik Kampung Wisata Keramik Dinoyo serta untuk menghindari klaim dari produk lain yang beredar. Frekuensi pelaksanaan terhadap produk dalam kategori tinggi (produk berkualitas) maka, strategi yang dilakukan oleh Kampung Wisata Keramik Dinoyo melakukan proses pembuatan dengan tepat waktu mulai dari persiapan pekerjaan sampai finishing pekerjaan

\section{c. Strategi Distribusi}




\section{Jurnal Komunikasi Nusantara}

E-ISSN. 2685-7650

Vol. 1 No. 1 (2019), pp 36-42

DOI: https://doi.org/10.33366/jkn.v1i1.8

Tipe strategi distribusi yang digunakan oleh Kampung Wisata Keramik Dinoyo adalah strategi distribusi langsung, melalui pengecer dan juga pemesan. Dari pola penggunaan saluran pemasaran dan strategi komunikasi perusahaan/industri, terlihat kecenderungan untuk menjangkau pasar sasaran dengan cara langsung, ecer dan juga melayani sejumlah pemesanan diberbagai wilayah domestik ataupun mancanegara. Hal ini mengindikasikan bahwa pihak menginginkan terjadinya kontak langsung antara pengrajin (sebagai produsen) dan konsumen (sebagai costumer), dengan demikian diharapkan adanya suatu hubungan (relationship) yang berkelanjutan. Pendekatan-pendekatan khusus (secara formal maupun informal) yang bertujuan mempengaruhi konsumen sasaran untuk melakukan pembelian menjadi salah satu taktik yang diterapkan untuk mendukung strategi ini.

\section{d. Strategi Promosi dan Komunikasi}

Salah satu cara yang dapat dilakukan untuk mempengaruhi tanggapan konsumen akan produk yang dihasilkan oleh Kampung Wisata Keramik Dinoyo adalah melalui promosi yang tepat hal ini diharapkan volume penjualan akan meningkat. Mengingat sebelumnya harga promos di media sangat mahal, sehingga promosi sebagai alat pemasaran cenderung hanya dimanfaatkan oleh perusahan-perusahaan besar saja, terutama melalui iklan. Namun Paguyuban dan para pengrajin di Kampung Wisata Keramik Dinoyo menggunakan promosi yang unik, yaitu kerab berdampingan dengan dinas pariwisata untuk melakukan event-event penting dan ternama, sebgaian penjual memasarkan dan mempromosikan melalui website, dan mengadakan event-event yang disponsori oleh penyelenggara. Dengan digunakannya media-media promosi tersebut terlihat bahwa Kampung Wisata Keramik Dinoyo memiliki tujuan untuk menjangkau pasar sasaran yang lebih luas.

Hal inilah yang memicu Kampung Wisata Keramik Dinoyo untuk merubah ke arah yang berbasis wisata sehingga dapat menarik minat pengunjung sehingga dapat mendongkrak penjualan produk. Kampung Wisata Keramik Dinoyo melakukan perencanaan segmentasi, targeting dan positioning. Kampung Wisata Keramik Dinoyo menetapkan segmentasi yang akan dituju adalah semua kalangan. Terkait dengan membangun brand identity sebagai Kampung Wisata dan untuk meningkatkan jumlah penjualan, Kampung Wisata Keramik Dinoyo menggunakan strategi IMC dengan pendekatan kepada segmen semua kalangan.

\section{Advertising}

Advertising yang digunakan Kampung Wisata Keramik Dinoyo untuk membangun awareness, mengkomunikasikan transformasi identitas brandnya baik itu tampilan, produk dan layanan konsumen. Melalui advertising, kelebihan-kelebihan yang menjadi keunggulan produk keramik yang ada di Kampung Wisata Keramik Dinoyo ditonjolkan baik dari segi produk, harga, pelayanan, iklan-iklan tersebut mengilustrasikan Kampung Wisata Keramik Dinoyo, “ kampong wisata Malang". Cara pengemasan merupakan hal penting bagi Kampung Wisata Keramik untuk menarik target pasarnya, mengingat segmentasi yang dituju adalah semua kalangan. Melalui iklan Kampung Wisata Keramik Dinoyo membangun identitasnya yang lebih menonjolkan kampong wisata. Namun Kampung Wisata Keramik Dinoyo juga tetap melakukan promosi melalui pendekatan untuk tetap menjaga konsumen. 


\section{Jurnal Komunikasi Nusantara}

E-ISSN. 2685-7650

Vol. 1 No. 1 (2019), pp 36-42

DOI: https://doi.org/10.33366/jkn.v1i1.8

\section{Workshop Brand Product}

Kampung Wisata Keramik Dinoyo menggunakan aktivitas aktivitas public relations dengan cara mengefektifkan pengurus paguyuban dan seluruh pengrajin yang terlibat untuk membangun hubungan atau relations serta menciptakan awareness dan knowledge masyarakat terhadap transformasi identitas brandnya. Hal itu diwujudkan dengan menyelenggarakan workshop brand product keramik Dinoyo. Kampung Wisata Keramik Dinoyo lebih banyak menggunakan pendekatan atau menyasar segmentasi semua kalangan dengan cara memberikan edukasi, secara langsung dan professional untuk aktivitas mengenalkan brandnya melalui event serta festival-festival yang bekerja sama dengan Pemerintah Kota Malang dan Dinas Pariwisata Malang.

\section{Online Marketing}

Website menjadi media yang digunakan untuk menjangkau konsumennya. Melalui website Kampung Wisata Keramik menawarkan dan memasarkan produk-produknya. Website tersebut juga menjadi salah satu media interaktif antara customer dengan pihak pengrajin. Didalamnya terdapat berbagai informasi tentang macam-macam produk keramik. Penataan atau layout website desain dibuat sesuai dengan kemampuan para pengrajin dan penjual, sehingga desainnya tetap menyesuaikan dengan produk yang dijual.

\section{Sales Promotion}

Sales promotion dimanfaatkan Kampung Wisata Keramik Dinoyo melalui pengecer untuk meningkatkan penjualan produk dengan menarik calon-calon konsumen. Kegiatan promosi penjualan yang dilakukan pihak Kampung Wisata Keramik Dinoyo untuk menarik konsumennya ini meliputi promo, selling product, dan sebagainya. Program promosi penjualan yang banyak dilakukan Kampung Wisata Keramik Dinoyo adalah dengan selling product. Dengan program tersebut Kampung Wisata Keramik Dinoyo lebih bisa merangkul konsumen yang menjadi target sasarannya yaitu semua kalangan sekaligus menonjolkan keunggulan-keunggulan serta merefleksikan perubahan identitas brandnya yang lebih ke arah wisata.

\section{Strategi Komunikasi Pemasaran dalam Menjaga Produk untuk Meningkatkan Hubungan Baik Dengan Customer}

Hasil pengamatan dalam pelaksanaan penelitian dan wawancara mendalam yang telah dilakukan menunjukkan bahwa strategi komunikasi pemasaran untuk menjaga hubungan baik dengan customer sebagian besar dilakukan oleh pihak lingkungan setempat terutama penghasil dan penjual secara langsung. Keberadaan masyarakat atau penjual produk memiliki fungsi manajemen masing-masing dari bagian Marketing yang ada di Kampung Keramik Dinoyo. Sesuai dengan visi misi dan tujuan yang dimiliki oleh Kampung Wisata Keramik Dinoyo, maka pemasaran yang dilakukan juga sejalan dengan hal tersebut. Yakni para penghasil dan penjual Keramik Dinoyo dalam menjaga hubungan baik dengan custemer kerap mengutamakan kepuasan pelanggan atas produk yang mereka tawarkan. 


\section{Jurnal Komunikasi Nusantara}

E-ISSN. 2685-7650

Vol. 1 No. 1 (2019), pp 36-42

DOI: https://doi.org/10.33366/jkn.v1i1.8

Untuk mencapai kepuasan pelanggan serta meraih dan mempertahankan konsumen yang lebih banyak lagi, Kampung Wisata Keramik Dinoyo menciptakan iklan, menerapkan promosi, melakukan pemasaran langsung, mengatur dan melaksanakan kegiatan-kegiatan event sehingga mampu menarik dan membina hubungan baik dengan konsumen dan masyarakat luas, hingga melakukan penjualan personal yang bisa menaikkan persentase jumlah konsumen tiap tahunnya. Pihak Kampung Wisata Keramik juga melakukan dan mengajak langsung masyarakat berpartisipasi dalam pengenalan produk, cara pembuatan produk dalam rangka memberikan edukasi.

\section{Kesimpulan}

Kampung Wisata Keramik Dinoyo melakukan strategi komunikasi pemasaran dengan menentukan tahap-tahap strategi komunikasi pemasaran dengan cara membuat perencanaan melalui pendekatan mix marketing (product) keramik, yang dikemas dengan innovasi terbaru dan beragam bentuk jenisnya. Mereka juga melakukan kerja sama dengan tujuan menuju sasaran yang tepat. Dengan menetapkan mulai dari harga yang terendah sampai tertinggi (Price) keramik ,contoh harga produk mulai dari harga Rp. 10.000. (promotion) keramik, menggunakan beberapa media, seperti channel youtube, facebook, media online dan instagram sebagai alat advertising, (place) pemilihan dan penempatan yang strategis untuk penjualan produk sangat menentukan sasaran pasar masyarakat guna menggunakan tempat dengan membuka toko-toko di area Wisata Keramik Dinoyo.

Strategi yang diterapkan dalam meningkatkan hasil penjualan keramik Dinoyo adalah dengan cara Advertising. Advertising yang digunakan Kampung Wisata Keramik Dinoyo untuk membangun awareness, mengkomunikasikan pesan untuk memperlihatkan identitas brandnya baik itu tampilan, produk dan pelayanan terhadap konsumen. Melalui advertising, kelebihankelebihan yang menjadi keunggulan produk keramik yang ada di Kampung Wisata Keramik Dinoyo ditonjolkan baik dari segi kualitas produk, harga, dan juga pelayanan. Selanjutnya Kampung Wisata Keramik Dinoyo juga melakukan Program Direct dan Online Marketing yang bertujuan untuk menarik calon konsumen dan merangkul atau menjalin hubungan dengan konsumennya, khususnya segmen semua kalangan melalui komunikasi serta mendapat respon secara langsung dan terukur dari konsumen serta calon konsumen. Kampung Wisata Keramik Dinoyo juga melakukan Personal Selling. Personal selling dilakukan untuk memperbesar tingkat pembelian dengan menjual produknya yang berkualitas dalam skala besar ke seluruh Indonesia dengan cara bekerjasama dengan Pemerintah Kota (PemKot) Dinas Pariwisata melalui event-event yang diadakan.

\section{Daftar Pustaka}

Afrilia, A. M. (2018). Digital Marketing Sebagai Strategi Komunikasi Pemasaran "Waroenk Ora Umum” Dalam Meningkatkan Jumlah Konsumen. Jurnal Riset Komunikasi, 1(1), 147-157. https://doi.org/10.24329/jurkom.v1i1.21

Aprilya, T. (2017). Strategi Komunikasi Pemasaran Nadyasfashop Melalui Instagram Dalam Meningkatkan Kepercayaan Customer Di Samarinda. EJournal Ilmu Komunikasi, 5(1), 1323.

Asrori, M. (2016). Pengertian, Tujuan Dan Ruang Lingkup Strategi Pembelajaran. MADRASAH, 


\section{Jurnal Komunikasi Nusantara}

E-ISSN. 2685-7650

Vol. 1 No. 1 (2019), pp 36-42

DOI: https://doi.org/10.33366/jkn.v1i1.8

5(2), 163-188. https://doi.org/10.18860/jt.v6i2.3301

Cangara, H. (2013). Komunikasi Politik Konsep Teori dan Strategi. Grasindo Persada.

Chaniago, S. A. (2014). Perumusan Manajemen Strategi Pemberdayaan Zakat. Jurnal hukum islam, 12(1), 87-101. https://doi.org/10.28918/jhi.v12i1.529

Kurnianti, A. W. (2017). Komunikasi Pemasaran Transportasi Online NGuberJEK. Jurnal Komunikasi Dan Kajian Media, 1(1), 69-84.

Kusniadji, S. (2016). Strategi Komunikasi Pemasaran Dalam Kegiatan Pemasaran Produk. Jurnal Komunikasi, 8(1), 83-98. https://doi.org/http://dx.doi.org/10.24912/jk.v8i1.49

Nurcholifah, I. (2014). Strategi Marketing Mix dalam Perspektif Syariah. Jurnal KhatulistiwaJournal Of Islamic Studies, 4(1), 73-86.

Suwatno. (2017). Komunikasi Pemasaran Kontekstual. Simbiosa Rekatama Media.

Wijaya, I. S. (2015). Perencanaan Dan Strategi Komunikasi Dalam Kegiatan Pembangunan. Lentera, XVIII(1), 53-61. https://doi.org/10.21093/lj.v17i1.428. 